\title{
Palaeoenvironmental evolution of the Southern Alps across the Faraoni Level equivalent: new data from the Trento Plateau (Upper Hauterivian, Dolomites, N. Italy)
}

\author{
ALEXANDER LUKENEDER $^{1}$ AND PATRICK GRUNERT ${ }^{2}$ \\ ${ }^{1}$ Natural History Museum, Geological-Paleontological Department, Burgring 7, A-1010 Vienna, Austria. \\ E-mail: alexander.lukeneder@nhm-wien.ac.at \\ ${ }^{2}$ University of Graz, Institute for Earth Sciences, Heinrichstraße 26, A-8010 Graz, Austria. \\ E-mail:patrick.grunert@uni-graz.at
}

\begin{abstract}
:
Lukeneder, A. and Grunert, P. 2013. Palaeoenvironmental evolution of the Southern Alps across the Faraoni Level equivalent: new data from the Trento Plateau (Upper Hauterivian, Dolomites, N. Italy). Acta Geologica Polonica, 63 (1), 89-104. Warszawa.
\end{abstract}

New stratigraphic and palaeoenvironmental data are presented for the northeastern part of the Trento Plateau (Puez area, Southern Alps, Italy). The studied section corresponds to the upper Hauterivian Balearites balearis and "Pseudothurmannia ohmi" ammonite zones and normal palaeomagnetic chron upper M5. A c. 30-cm-thick bed is identified as the equivalent of the Faraoni Level, based on its position within the Pseudothurmannia mortilleti Subzone, the composition of its ammonite fauna and the peak of a minor positive trend in the $\delta^{13} \mathrm{C}_{\mathrm{bulk}}$ record. Microfacies and geochemical proxies compare well with those of the southeastern part of the Trento Plateau and indicate palaeoceanographic continuity along the eastern margin of the plateau. The abundances of radiolarians and nannoconids suggest a turnover in the trophic structure from eutrophic conditions around the Faraoni Level equivalent to oligotrophic conditions. Low organic matter and sulphur content and frequent bioturbation indicate a well-oxygenated environment.

Ammonite diversity and life-habitat groups document the influence of sea level on the plateau: while epi- and mesopelagic ammonites occur commonly during sea-level highstands, all life-habitat groups become reduced during a sea-level lowstand in the Spathicrioceras seitzi and P. ohmi subzones. The Faraoni event is heralded by a faunal turnover expressed as the diversification of epipelagic ammonites.

Palaeoenvironmental conditions along the eastern margin of the Trento Plateau during the Faraoni event contrast with those of the organic-rich black shales in the west. A re-evaluation of the depositional model based on the new results suggests a general water depth of 300-500 m for the plateau. The severe reduction of mesopelagic ammonites during the sea-level lowstand indicates a shallowing towards the epi-/mesopelagic boundary. During the Faraoni event, the eastern areas of the Trento Plateau were located at the upper limit of the oxygen-minimum layer and were thus only occasionally affected by oxygen depletion, whereas the western areas were located well within the upper part of the oxygen-depleted layer.

Key words: Lower Cretaceous; Hauterivian; Faraoni oceanic anoxic event; Trento Plateau; Dolomites; Italy. 


\section{INTRODUCTION}

The latest Hauterivian represents a period of major palaeoenvironmental change expressed most prominently as a turnover in ammonite faunas and the drowning of the northern Tethyan carbonate platform (Company et al. 2005; Föllmi 2012). The observed change coincides with the Faraoni anoxic event, one of the first distinctive perturbations of the carbon cycle during the early Cretaceous. In the sedimentary record, this short-lived oxygen-deficient event is reflected in the widespread deposition of organic-rich black shales throughout the western Tethys realm (Cecca et al. 1994a, b; Cecca et al. 1996; Faraoni et al. 1996; Baudin et al. 1997; Coccioni et al. 1998; Baudin et al. 1999; Erba et al. 1999; Bersezio et al. 2002; Baudin et al. 2002; Bellanaca et al. 2002; Busnardo et al. 2003; Baudin 2005; Company et al. 2005; Coccioni et al. 2006; Bodin et al. 2007; Bodin et al. 2009; Tremolada et al. 2009; Föllmi et al. 2011). In the isotopic records, the Faraoni event is expressed as the culmination of a minor long-term increase in $\delta^{13} \mathrm{C}$, thereby contrasting with major carbon isotope excursions related to other Cretaceous anoxic events (Föllmi et al. 1994; Erba et al. 1999; Schootbrugge et al. 2000; Company et al. 2005; Godet et al. 2006). The processes contributing to the Faraoni event are subject to ongoing debate. Eutrophication of the Tethys Sea during the latest Hauterivian has been linked to (1) the combined effects of a eustatic sea-level rise resulting in the flooding of large epicontinental areas (Bodin et al. 2006) and the inflow of nutrient-rich boreal waters (Mutterlose and Bornemann 2000; Bodin et al. 2006; Godet et al. 2006); (2) a warm and humid climate, resulting in increased weathering rates (Godet et al. 2008) and en- hanced salinity stratification of the water column due to increased river input (Bodin et al. 2009); (3) intensified phosphorus reflux from anoxic sediments (Bodin et al. 2006; Bodin et al. 2009); and (4) increased upwelling along the northern Tethyan margin (Bodin et al. 2006).

During this period of palaeoenvironmental change, the Trento Plateau formed a topographic high within the Tethys, located at the easternmost extension of organic-rich black shales associated with the Faraoni Event (Text-figs 1, 2; Dercourt et al. 1993; Barrier and Vrielynck 2008). Previous studies of the Faraoni Level have documented the complex history of the southern part of the Trento Plateau, reflected in an west-east gradient in lithology and abundant organic matter (Baudin et al. 1997; Erba et al. 1999; Tremolada et al. 2009). The present paper contributes comparable data for the northern margin of the plateau in the Puez region (Text-fig. 1). Upper Hauterivian deposits including the equivalent of the Faraoni Level will be stratigraphically constrained by integrating bio-, magneto- and chemostratigraphy. Trends in ammonite faunas, microfacies and geochemical proxies will provide new information on the local palaeoenvironment that - in comparision with data from localities from the southern part of the Trento Plateau - will help to re-evaluate the depositional model for the area.

Following Bodin et al. (2007), the term "Faraoni Level" will be used herein when the lithological characteristics are the same as in the type area (Cecca et al. 1994; Text-fig. 3), whereas the term "Faraoni Level equivalent" is used when the lithology differs from that of the type area (i.e. lacking a distinct enrichment in organic matter).

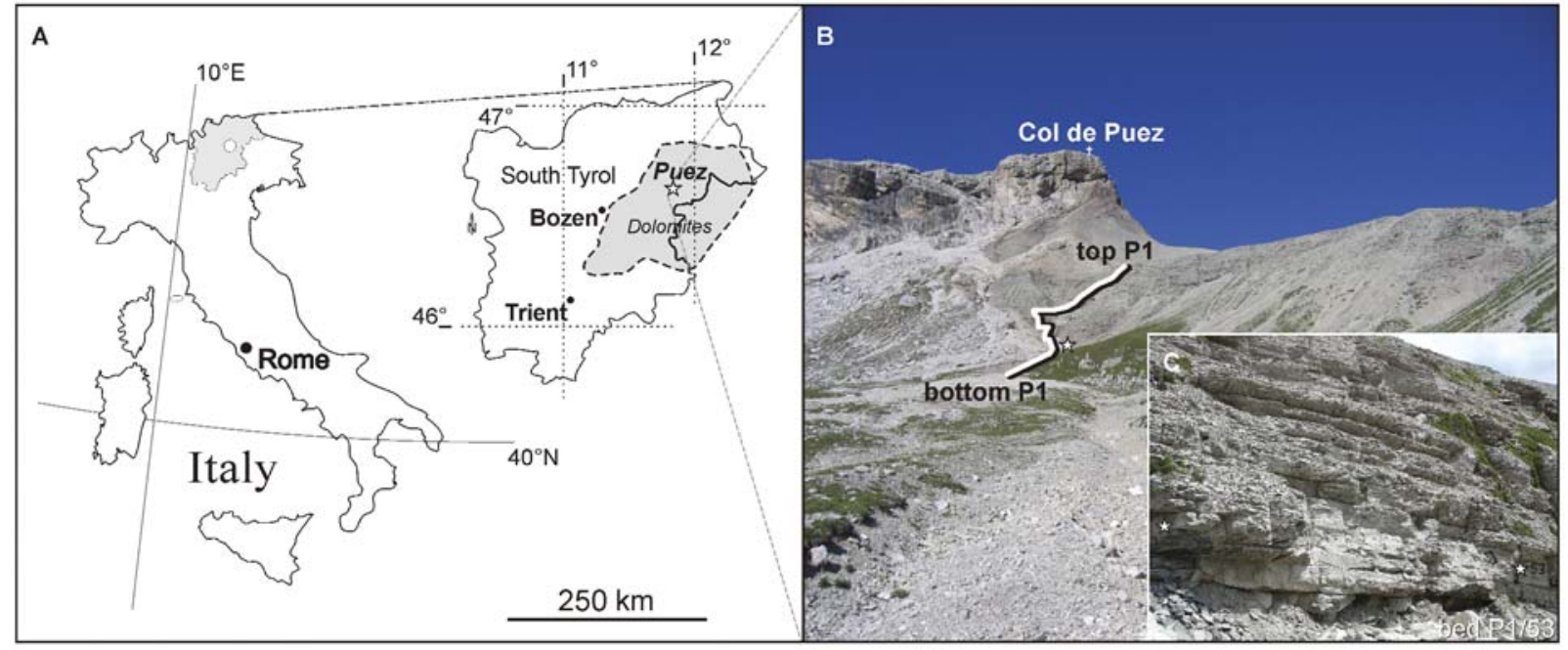

Text-fig. 1. The Lower Cretaceous Puez area. A - Puez area (white star) and outcrop position (P1) within the Dolomites (South Tyrol, Italy). B - Position of the Puez locality on the northern Trento Plateau. C - East-west transect of the Lower Cretaceous Trento Plateau and adjacent basins 
EVOLUTION OF THE SOUTHERN ALPS

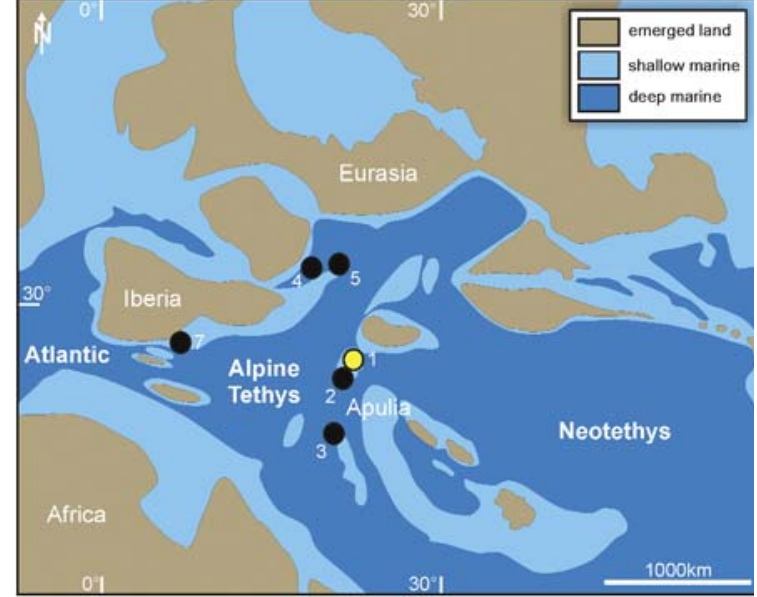

Text-fig. 2. Palaeogeographic map of the Mediterranean area during the Late Hauterivian based on Dercourt et al. (1993) and Barrier and Vrielynck (2008). Numbers indicate localities of the Faraoni Level and equivalents: 1 - Trento Plateau, 2 - Lessini Mountains, 3 - Umbria Marche, 4 - Angles, 5 - Veveyse de Châtel-St. Denis, 7 - Rio Argos

\section{GEOLOGICAL SETTING AND STUDY AREA}

The Permian to Cretaceous deposits of the Dolomites in northern Italy constitute an internal part of the Southern Alps that emerged during the deformation of the passive continental margin of the Adriatic (=Apulian) Plate of the South Alpine-Apennine Block (Dercourt et al. 1993; Bosellini 1998; Cecca 1998; Stampfli and Mosar 1999; Scotese 2001; Stampfli et al. 2002; Bosellini et al. 2003). This block was limited by the Penninic Ocean (=Alpine Tethys) to the north and the Vardar Ocean to the southeast (Scotese 2001; Stampfli et al. 2002). During the Early Cretaceous, the Dolomites formed a part of the Trento Plateau that extended from the area around Trento in the south to the Puez region in the north (Geyer 1993; Baudin et al. 1997; Bosellini et al. 2003; Lukeneder 2008). It was one of several topographic highs located in the Tethys that contributed to the complex palaeogeography of the Early Cretaceous (Text-fig. 2; Dercourt et al. 1993). The

\section{Umbria Marche}
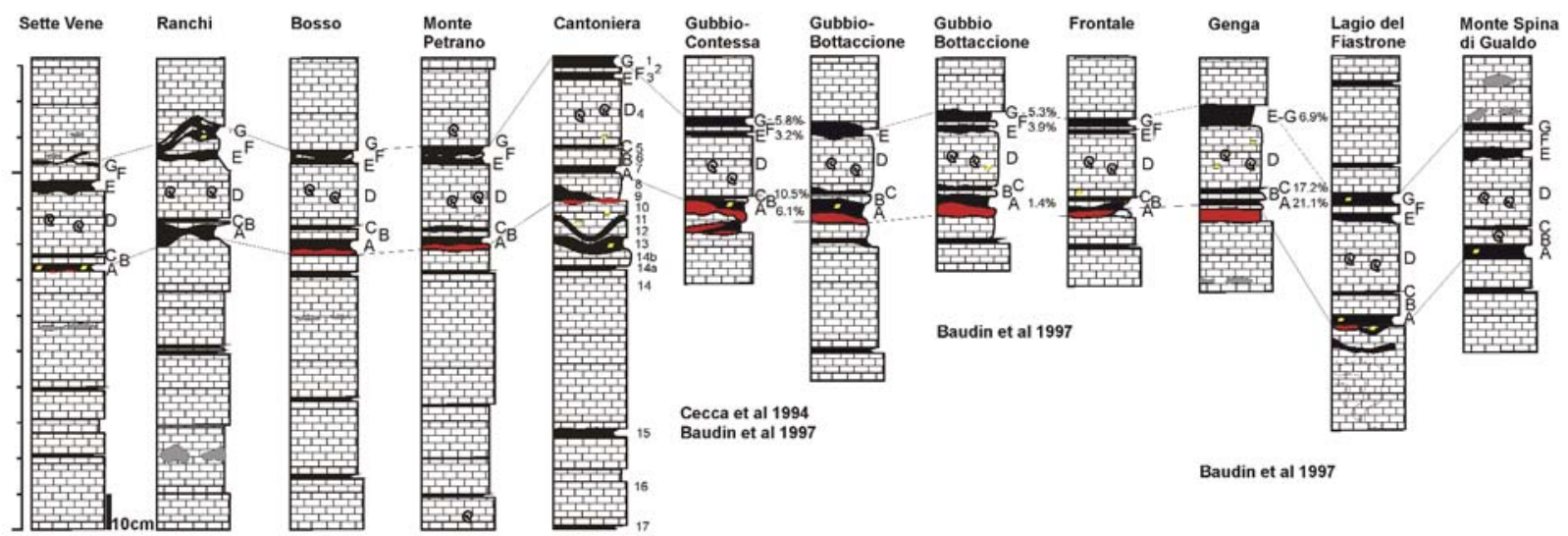

Baudin et al 1997

\section{W Trento Plateau}

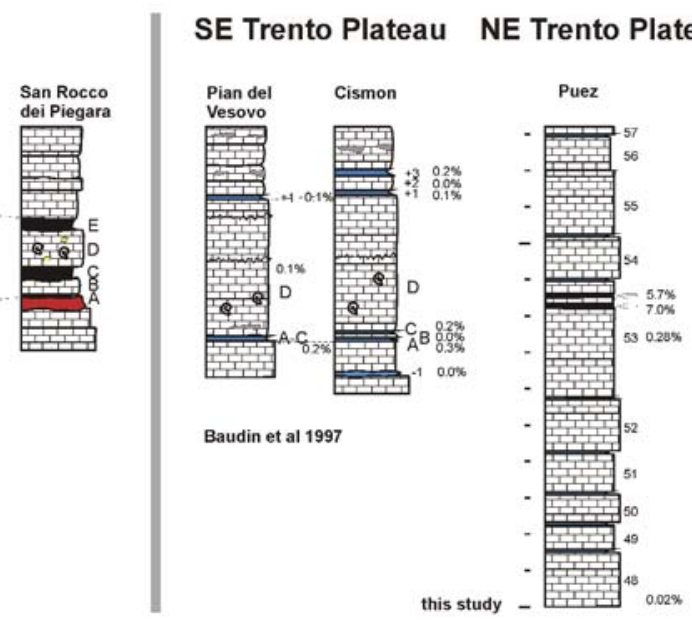

SE Trento Plateau NE Trento Plateau

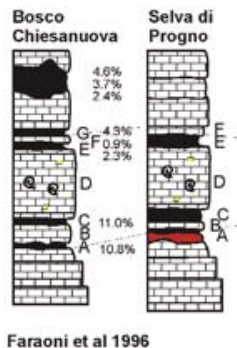

Faraoni et al 1996

this study

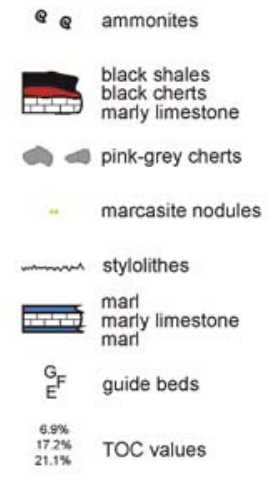

Text-fig. 3. Lithological characteristics of the Upper Hauterivian Faraoni Level and Faraoni Level equivalents from the south (Umbria Marche; Cecca et al. 1994, Baudin et al. 1994) to the north of Italy (Lessini Mountains, Dolomites; Faraoni et al. 1996, Baudin et al. 1997, Lukeneder 2010, this study). Lithology of the Puez section follows Lukeneder (2010) and includes two organic-rich black shale intervals recently discovered 50m east of the Puez 1 section. See text for details 


\section{ALEXANDER LUKENEDER AND PATRICK GRUNERT}

Trento Plateau was formerly surrounded by two basins: the Lombardian Basin to the west and the Belluno Basin to the east (Text-fig. 1; Lukeneder 2010). According to recent investigations by Muttoni et al. (2005), the Lombardian Basin - and thus the adjacent Trento Plateau was located at approximately $20^{\circ} \mathrm{N}$ during the Valanginian and Hauterivian.

The studied section Puez 1 is located on the PuezOdle-Gardenaccia Plateau in the northern Dolomites, about $30 \mathrm{~km}$ northeast of Bozen (E 011 ${ }^{\circ} 49^{\prime} 15^{\prime}$, , N 46'35'30"; Text-fig. 1A). The study area at the Col de Puez represents the stratotype for the Puez Formation, which comprises the Puez Limestone, Puez Redbed and Puez Marl members (see Lukeneder 2010 for details). Biostratigraphic constraints from ammonites and microfossils indicate a Valanginian to Albian age for the hemipelagic to pelagic deposits (Lukeneder 2010, 2012). The present study focuses on the middle part of the Puez Limestone Member. The selected 14.5-mthick interval corresponds to beds P1/21 to P1/71e and is correlated with the Upper Hauterivian to Lower Barremian Balearites balearis and Pseudothurmannia ohmi zones (Text-fig. 3; Lukeneder 2012). The lithology shows a transition from limestones and marly limestones into a marl-marly limestone alternation in the upper half of the section (Lukeneder 2010). Two black shale intervals, approximately 5 and $15 \mathrm{~cm}$ thick and correlatable to the upper part of bed $\mathrm{P} 1 / 53$, have been recently detected at a new section located $50 \mathrm{~m}$ east of the Puez 1section (Text-fig. 3).

\section{MATERIAL AND METHODS}

Carbon isotope stratigraphy and magnetostratigraphy were applied and integrated with the available ammonite biostratigraphy in order to correlate the section and the equivalent of the Faraoni Level to the geological time scale (Ogg et al. 2008). Information on the palaeoenvironment is derived from the analyses of ammonite assemblages, microfacies and contents of total organic carbon, sulphur, and nitrogen. The studied sample material was collected in the scope of FWF project P20018-N10 and is stored at the South Tyrol Museum of Natural Sciences (Bozen) and the Natural History Museum (Vienna).

\section{Magnetostratigraphy}

Twenty-four samples were used for palaeomagnetic analyses at the University of São Paulo (Brazil) and the Istitute Nazionale di Geofisica e Vulcanologfia in Rome (Italy). All samples were subjected to progressive thermal demagnetization or alternating field demagnetization in 11 to 12 temperatures or fields. The individual components were precisely established using multicomponent analysis of remanence (Kirschvink 1980). Isothermal remanent magnetization to saturation was measured to identify magnetically active minerals. Natural remanences and demagnetizations were measured. Alternating field demagnetization was applied in steps of $0,5,10,15,20,25,30,35,40$, $50,60,70,80,90,100 \mathrm{mT}$. Based on the Principal Component Analysis of the demagnetization patterns, the inclination and declination of the Characteristic Remanent Magnetization were defined, allowing the identification of the corresponding polarity chrons. The component declination and inclination were plotted against stratigraphic thickness depth. We exclusively used samples that represent the maximum angular deviation (MAD) with values $<14^{\circ}$, indicating that the components are well defined.

\section{Chemostratigraphy}

Twenty-eight bulk rock samples were analysed for stable isotopes of carbon $\left(\delta^{13} C_{\text {bulk }}\right)$. Measurements were preformed at the laboratories of the CNR Istituto Ambiente Marino Costiero in Naples (IAMC-CNR; Italy) and the Institute for Earth Sciences of the University of Graz (Austria). The isotope laboratory at the IAMC-CNR uses an automated continuous flow carbonate preparation GasBenchII device (Spötl and Vennemann 2003) and a ThermoElectron Delta Plus XP mass spectrometer. Dried samples were acidified at $50^{\circ} \mathrm{C}$. Analytical precision based on replicate analysis of the international laboratory standard NBS 19 and an internal standard is estimated at $0.1 \%$ for $\delta^{13} \mathrm{C}$. At the isotope laboratory of the University of Graz, a Kiel II preparation line and Finnigan MAT Delta Plus mass spectrometer were used. Samples were dried and reacted with $100 \%$ phosphoric acid at $70^{\circ} \mathrm{C}$. Analytical precision based on replicate analysis of the international standard NBS 19 and internal laboratory standards is better than $0.04 \%$ for $\delta^{13} \mathrm{C}$. Results are reported in per mil (\%o) relative to the Vienna Pee Dee Belemnite standard (VPDB).

The stable isotope record of bulk rock samples is considered to preserve palaeoenvironmental signals of the surface water. Due to the preferential uptake of ${ }^{12} \mathrm{C}$ during photosynthesis, $\delta^{13} \mathrm{C}_{\text {bulk }}$ is used to determine local changes in phytoplankton productivity (e.g., Weissert 1989). Major excursions in $\delta^{13} \mathrm{C}_{\text {bulk }}$ additionally reflect perturbations of the global carbon cycle and are thus used for stratigraphic correlation (Weissert et al. 2008). 


\section{Ammonite assemblages}

The macrofossil record of the studied interval is dominated by ammonoids co-occurring with echinoids. The ammonoids are preserved as steinkerns without shell preservation. Fossils were collected using hammers and chisels and prepared using air pressure vibro-tools.

The present study focuses on the palaeoecological implications of changes in the composition of the ammonoid assemblages. Diversity of the ammonite assemblages, which has been suggested to be related to sea-level change (Hoedemaeker 1995; Company et al. 2005), is expressed as the number of species per bed and by the Shannon index, as well as by the number of families per ammonite subzone. Furthermore, Westermann (1996) and Company et al. (2005) suggested that variations in the abundance of different ammonoid morphological groups resulted from changes in nutrient availability and the oxygenation of the water column. Accordingly, Company et al. (2005) developed a classification of ammonites into six life-habitat groups: planktic drifters, epipelagic vertical migrants, epipelagic nektic ammonites, mesopelagic vertical migrants, mesopelagic nektic ammonites, and nektobenthic ammonites. These categories are adopted for the present study and all ammonite species from Puez were assigned to the respective life-habitat groups (Text-figs 4, 5). For the interpretation, planktic drifters and epipelagic vertical migrants as well as mesopelagic vertical migrants and mesopelagic nektonic ammonites were grouped together due to uncertainties regarding their mode of life (Company et al. 2005).

\section{Microfacies}

Microfacies analysis is based on thin sections from 17 beds. Nomenclature and description follow Dunham (1962). Analyses were carried out at the Geological Institute of the Slovak Academy of Science and at the Department of Geology and Palaeontology of the Comenius University (Slovakia).

\section{Total organic carbon (TOC), total sulphur (TS) and total nitrogen (TN)}

17 samples were measured by using a LECO WR12 analyser at the Department of Forest Ecology of the University of Vienna (Austria) and a LECO CS-300 analyser at the Institute for Earth Sciences of the University of Graz (Austria). The sample material includes two samples (Pnew/1, Pnew/2) from the black shale ayers exposed in the new section $50 \mathrm{~m}$ east of the
Puez 1 section (Text-fig. 3). All results are given in wt $\%$ bulk rock.

TOC was calculated as the difference between total carbon and carbonate carbon, assuming that all carbonate is pure calcite (Arthur et al. 1986). TOC describes the quantity of organic matter in a given sample and reflects the production of organic matter as well as preservation (Hunt 1996). The latter depends on the origin of the organic matter (terrestrial/marine), oxygenation of the water column and the sediment, the degree of bioturbation, and the sedimentation rate (Hunt 1996; Peters et al. 2005).

Sulphur content primarily reflects the degree of sulphate-reducing bacterial activity and serves as an indicator of bottom-water oxygenation (Peters et al. 2005).

TN was determined in order to calculate $\mathrm{C} / \mathrm{N}$ (TOC vs TN) ratios. The $\mathrm{C} / \mathrm{N}$ ratio reflects the origin of organic matter: organic matter of terrestrial origin typically results in $\mathrm{C} / \mathrm{N}>15$, while marine $\mathrm{OM}$ results in ratios of $\leq 5$ (e.g., Emerson and Hedges 1988; Wagner and Dupont 1999).

\section{RESULTS}

\section{Magnetostratigraphy}

All samples revealed normal polarity. Magnetomineralogical analyses and unblocking temperature determination show that magnetite and goethite are the main carriers of remanent magnetization. The mean inclination values represent values approx. at $45^{\circ}$.

\section{Chemostratigraphy}

$\delta^{13} \mathrm{C}_{\text {bulk }}$ values ranged from $1.4 \%$ to $2.2 \%$ and showed a threefold trend (Table 1, Text-fig. 6): a slow increase of about $0.2 \%$ in the Crioceratites krenkeli Subzone (P1/21 to P1/43) is followed by an abrupt increase of about $0.4 \%$ in the Spathicrioceras seitzi and Pseudothurmannia ohmi subzones (P1/47). Values in the Pseudothurmannia mortiletti Subzone (P1/50-65) remained rather stable, with the highest value of $2.2 \%$ in $\mathrm{P} 1 / 53$. A slight decrease in $\delta^{13} \mathrm{C}_{\text {bulk }}$ values was observed within the Pseudothurmannia picteti Subzone (P1/66-71).

\section{Ammonite assemblages}

Thirty-six ammonite taxa are described from the studied section (Text-fig. 4). The number of species 
P1/21, Biomicritic, slightly bioturbated limestone, radiolarian-sponge packstone with thin laminae rich in small skeletal fragments and pyrite accumulations. Biogenic components: dominated by calcified radiolarians, sponge spicules, bivalve fragments and rare calpionellid loricas (Tintinnopsella carpathica, Crassicollaria sp.).

P1/27a, Biomicritic, slightly laminated limestone, nannoconid mudstone with thin laminae rich in small indeterminate skeletal fragments and abundant pyrite. Biogenic components: crinoids, bivalves, thin-shelled ostracods, hyaline foraminifers. Rare calpionellids (?Remaniella sp.) and dinoflagellates ( $\mathrm{Ca}$ dosina semiradiata cieszynica, Colomisphaera sp.) occur.

$\mathbf{P 1 / 2 7 b}$, Biomicritic, slightly laminated limestone, nannoconid mudstone with thin laminae rich in small indeterminate skeletal fragments and frequent pyrite. Biogenic components: crinoids, bivalves, thin-shelled ostracods, hyaline foraminifers, Involutina sp., calpionellid loricas.

$\mathbf{P 1 / 3 5}$, Biomicritic, slightly laminated and bioturbated limestone, sponge-radiolarian wackestone to packstone. Biogenic components: silicified radiolarians and sponge spicules dominate over rare bivalves and thin-shelled ostracods.

P1/38a, Biomicrite, slightly laminated and bioturbated limestone, mudstone. Biogenic components: rare sponge spicules, bivalves, crinoids, thin-shelled ostracods, hyaline foraminifers, Involutina sp., calpionellid loricas, and dinoflagellates ( $\mathrm{Ca}$ dosina semiradiata semiradiata)

$\mathbf{P 1 / 3 8 b}$, Biomicrite, slightly laminated and bioturbated limestone, mudstone. Biogenic components: rare sponge spicules, bivalves, crinoids, thin-shelled ostracods, hyaline foraminifers Involutina sp. is quite common.

P1/43, Biomicritic, slightly laminated limestone, mudstone Biogenic components: thin-shelled ostracods dominate over less common calcified radiolarians and rare bivalve, crinoid, hyaline and agglutinated foraminifers and aptychi fragments. Involutina sp., and Cadosina semiradiata cieszynica were identified.

P1/47, Biomicritic, slightly laminated limestone of radiolarian microfacies (wackestone). Biogenic components: silicified radiolarians dominate over sponge spicules and thin-shelled ostracods.

$\mathbf{P 1 / 5 3}$, Biomicritic, slightly laminated and bioturbated limestone of radiolarian microfacies (wackestone). Biogenic components: silicified radiolarians dominate over sponge spicules and thin-shelled ostracods. The clastic admixture is represented by silty quartz grains and muscovite.
P1/60, Biomicritic, slightly laminated limestone, mudstone. Biogenic components: thin-shelled ostracods dominate over less common calcified radiolarians and rare hyaline foraminifers and aptychi fragments. The clastic admixture is represented by silty quartz grains and muscovite. The limestone contain chert nodule composed of silicified radiolarians.

P1/65, Biomicrite, slightly laminated limestone, nannoconid mudstone. Biogenic components: thin-shelled ostracods, rare bivalve and crinoid fragments, hyaline and agglutinated foraminifers, dinoflagellates (Stomiosphaera wanneri, Colomisphaera heliosphaera, Colomisphaera sp.).

P1/68, Biomicrite, slightly laminated and bioturbated limestone, nannoconid mudstone. Biogenic components: thinshelled ostracods, rare aptychi, bivalve and crinoid fragments, hyaline foraminifers, dinoflagellates (Stomiosphaera wanneri, Colomisphaera sp.).

P1/71a, Biomicritic, slightly laminated and bioturbated limestone, nannoconid mudstone rich in silty clastics. Biogenic components: fragments belong to thin-shelled ostracods, rare bivalve and crinoid fragments, hyaline and agglutinated foraminifers (Lenticulina sp., Spirillina sp., Involutina sp., Gaudryina sp.), dinoflagellates (Stomiosphaera wanneri, Colomisphaera sp.).

P1/71b, Biomicritic, marly limestone of radiolarian microfacies (wackestone). Biogenic components: silicified radiolarians filled by chalcedony dominate over sponge spicules, thin-shelled ostracods and foraminifers (Spirillina sp.) The clastic admixture is represented by silty quartz grains and muscovite. The micritic matrix is rich in nannoplankton.

P1/71c, Biomicritic, slightly laminated and bioturbated limestone, nannoconid mudstone rich in silty clastics. Biogenic components: calcified radiolarians and sponges, thin-shelled ostracods, rare bivalve, crinoid and echinoid fragments, hyaline and agglutinated foraminifers (Lenticulina sp., Spirillina sp., Involutina sp.), dinoflagellates (Stomiosphaera wanneri, Colomisphaera sp.) and globochaets (Globochaete alpina).

P1/71d, Biomicrite, slightly laminated and bioturbated limestone, nannoconid mudstone. Biogenic components: thinshelled ostracods, rare crinoid and echinoid fragments, hyaline and agglutinated foraminifers (Lenticulina sp., Spirillina sp., Involutina sp.), dinoflagellates (Stomiosphaera wanneri, Colomisphaera heliosphaera).

P1/71e, Biomicrite, slightly laminated and bioturbated limestone, nannoconid mudstone. Biogenic components: thin-shelled ostracods, rare bivalve, crinoid and brachiopod fragments, hyaline and agglutinated foraminifers (Lenticulina sp., Spirillina sp., Involutina sp.), dinoflagellates (Stomiosphaera wanneri, Colomisphaera heliosphaera). 
steadily increased from a mean value of one at the base of the C. krenkeli Subzone to a mean of four species in the Pseudothurmannia picteti Subzone. Distinctive maxima occurrred at the base and top of the P. mortilleti Subzone, with eight and nine species respectively. The trend in species numbers was also reflected by the Shannon index, which increases from a mean of $0.9(\mathrm{~min}=$ $0.0, \max =1.8)$ in the Balearites balearis Zone to a mean of $1.6(\min =0.6, \max =2.6)$ in the "Pseudothurmannia ohmi" Zone (Text-fig. 5; Lukeneder 2012).

The number of ammonite families decreased from eight in the C. krenkeli Subzone to a minimum of six in the S. seitzi and P. ohmi subzones. Beginning with the $P$. mortilleti Subzone, family diversity increased from nine to twelve in the $P$. picteti Subzone.

Members of all life-habitat groups occur in the studied interval (Text-figs 4, 5). Planktic drifters are represented by Crioceratites, Pseudothurmannia, Paracostidiscus, Paraspiticeras, Karsteniceras, Hamulinites, Sabaudiella and Megacrioceras; the epipelagic vertical migrants are Honnoratia, Hamulina, and Anahamulina. Mesopelagic vertical migrants are represented by Lytoceras and Protetragonites, and the mesopelagic nektic ammonites include Phylloceras, Phyllopachyceras, Kotetishvilia and $\mathrm{Ne}$ olissoceras. Epipelagic nektic ammonites are repre- sented by Barremites, Plesiospitidiscus and Discoidellia. Finally, nektobenthic forms are represented by Abrytusites and Astieridiscus.

Trends within the life-habitat groups resemble the trend observed at the family level and show a conspicuous change in the Spathicrioceras seitzi and Pseudothurmannia ohmi subzones. Epipelagic vertical migrant and planktic drifters appear with three species in the Crioceratites krenkeli Subzone and are reduced to one species in the $S$. seitzi-P. ohmi subzones. This minimum is followed by a strong increase up to six species in the Psuedothurmannia mortilleti Subzone and remains high in the $P$. picteti Subzone with five species. The rare group of epipelagic-nektic (e.g. epipelagic swimmers) ammonites was represented by one species in the $C$. krenkeli Subzone and by none in the $S$. seitzi and P. ohmi subzones. They reappear with two species in the $P$. mortilleti Subzone, and one species is documented from the $P$. picteti Subzone (Text-figs 4, 5). Mesopelagic vertical migrant and mesopelagic nektic ammonoids show constant values of five species in the $C$. krenkeli, the $P$. mortilleti and the $P$. picteti subzones, interupted only by a strong drop to one species in the $S$. seitzi and $P$. ohmi subzones. Nektobenthic species are very rare and occur in the $C$. krenkeli and the P. picteti Subzones.

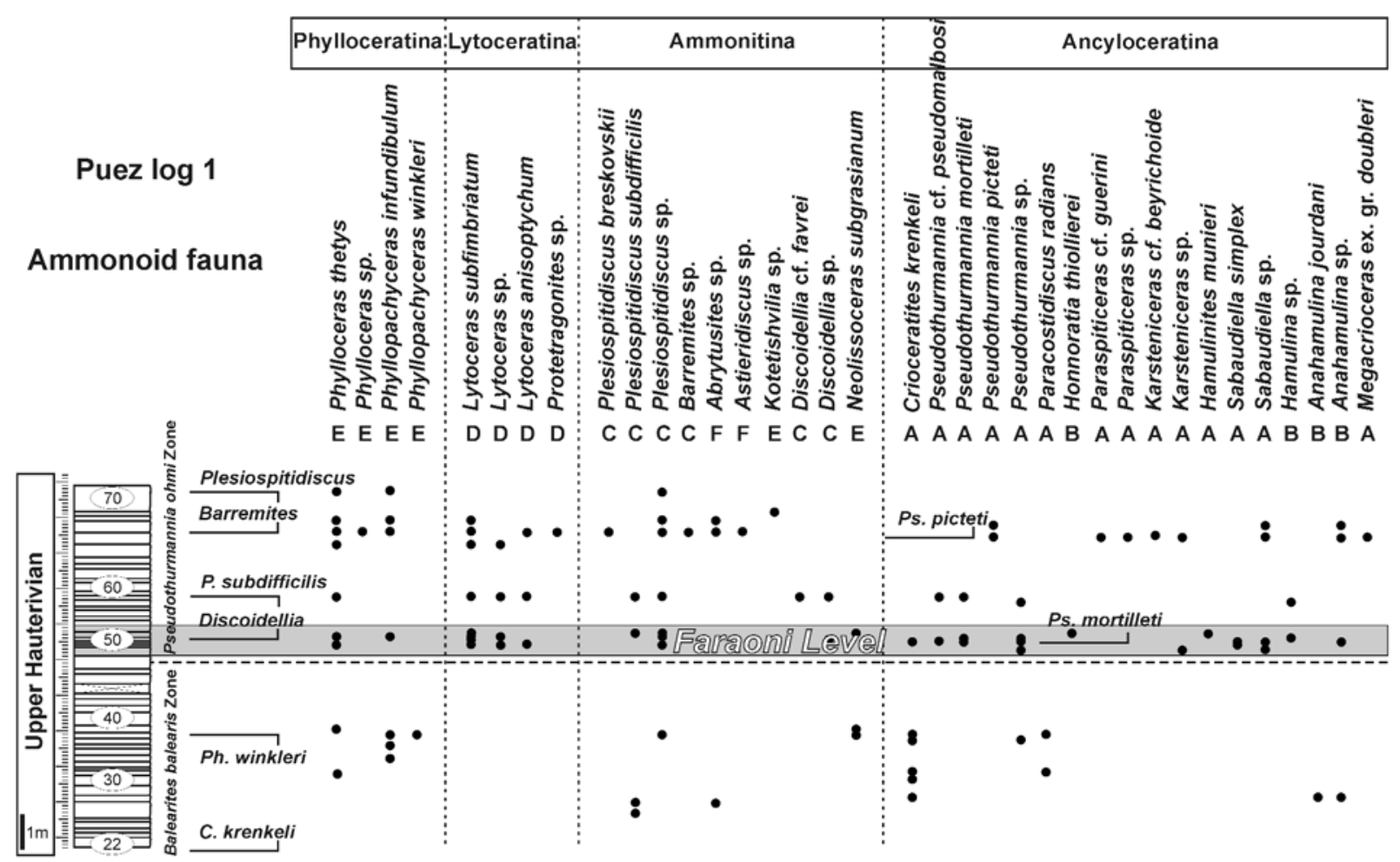

Text-fig. 4. Ammonite assemblages from the Puez locality. The Upper Hauterivian Faraoni Level equivalent is indicated in light grey. Life-habitat groups are adopted from Company et al. (2005): (A) planktic drifters, (B) epipelagic vertical migrants, (C) epipelagic nekton, (D) mesopelagic vertical migrants, (E) mesopelagic nekton 


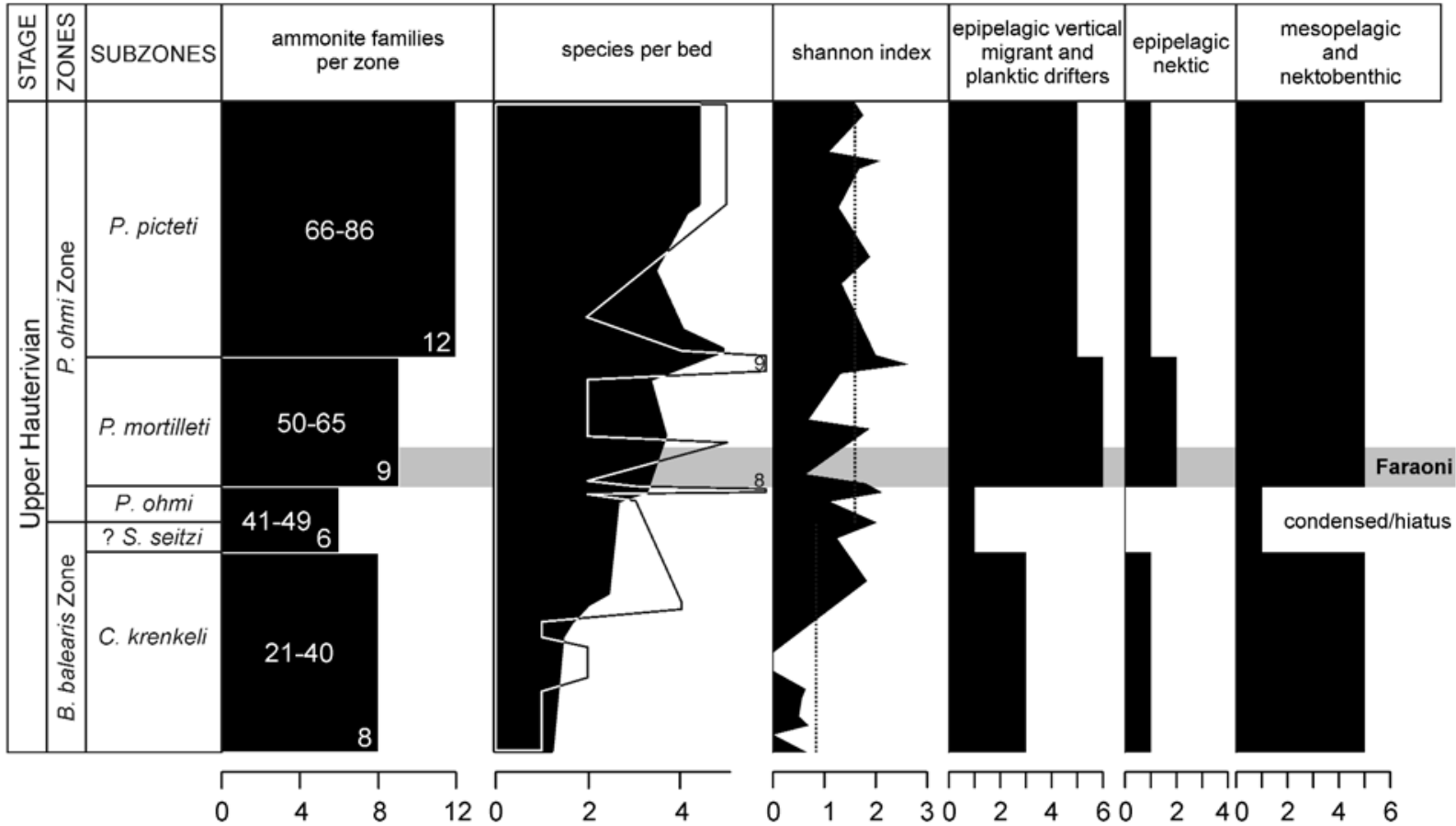

\begin{tabular}{|l|c|c|c|c|c|}
\hline Sample & $\mathbf{d 1 3 C}$ & TOC & TS & TN & C/N \\
\hline P1/21 & 1.40 & 0.04 & 0.32 & 0.05 & 0.71 \\
\hline $\mathrm{P} 1 / 27$ & 1.62 & 0.00 & 0.35 & 0.05 & 0.00 \\
\hline $\mathrm{P} 1 / 33$ & 1.75 & & & & \\
\hline $\mathrm{P} 1 / 35$ & 1.68 & 0.00 & 0.34 & 0.05 & 0.00 \\
\hline $\mathrm{P} 1 / 37$ & 1.69 & & & & \\
\hline $\mathrm{P} 1 / 38$ & 1.67 & 0.05 & 0.36 & 0.05 & 0.97 \\
\hline $\mathrm{P} 1 / 43$ & 1.61 & 0.24 & 0.38 & 0.06 & 3.99 \\
\hline $\mathrm{P} 1 / 47$ & 2.02 & 0.02 & 0.33 & 0.06 & 0.39 \\
\hline $\mathrm{P} 1 / 48$ & 1.96 & & & & \\
\hline $\mathrm{P} 1 / 49$ & 1.85 & & & & \\
\hline $\mathrm{P} 1 / 50$ & 1.98 & & & & \\
\hline $\mathrm{P} 1 / 51$ & 1.93 & & & & \\
\hline $\mathrm{P} 1 / 52$ & 2.06 & & & & \\
\hline $\mathrm{P} 1 / 53$ & 2.20 & 0.28 & 0.51 & 0.09 & 3.13 \\
\hline $\mathrm{P} n \mathrm{w} / 1$ & & 7.00 & 2.40 & & \\
\hline $\mathrm{Pnew} / 2$ & & 5.70 & 2.70 & & \\
\hline $\mathrm{P} 1 / 57$ & 2.03 & & & & \\
\hline $\mathrm{P} 1 / 58$ & 2.06 & & & & \\
\hline $\mathrm{P} 1 / 60$ & 1.88 & 0.00 & 0.33 & 0.06 & 0.00 \\
\hline $\mathrm{P} 1 / 62$ & 1.93 & & & & \\
\hline $\mathrm{P} 1 / 65$ & 2.08 & 0.00 & 0.34 & 0.06 & 0.00 \\
\hline $\mathrm{P} 1 / 66$ & 2.03 & & & & \\
\hline $\mathrm{P} 1 / 67$ & 2.04 & & & & \\
\hline $\mathrm{P} 1 / 68$ & 2.15 & 0.00 & 0.39 & 0.07 & 0.00 \\
\hline $\mathrm{P} 1 / 71 \mathrm{a}$ & 1.91 & 0.21 & 0.34 & 0.07 & 3.22 \\
\hline $\mathrm{P} 1 / 71 \mathrm{~b}$ & 1.96 & 0.25 & 0.42 & 0.06 & 4.12 \\
\hline $\mathrm{P} 1 / 71 \mathrm{c}$ & 1.92 & 0.00 & 0.37 & 0.06 & 0.00 \\
\hline $\mathrm{P} 1 / 71 \mathrm{~d}$ & 1.87 & 0.01 & 0.38 & 0.06 & 0.21 \\
\hline $\mathrm{P} 1 / 71 \mathrm{e}$ & 1.80 & 0.03 & 0.37 & 0.07 & 0.44 \\
\hline & & & & & \\
\hline
\end{tabular}

Text-fig. 5. Ammonite diversity and inferred life-habitat groups around the Faraoni Level equivalent of Puez 1 section

\section{Microfacies}

Details on the microfacies of each thin section are summarized in Table 2. In general, four microfacies types are distinguished: radiolarian-sponge wackestone to packstone, radiolarian wackestone, nannoconid mudstone and mudstone. While radiolariandominated microfacies occur predominantly from the C. krenkeli to the lower P. mortilleti subzones (P1/21 to $\mathrm{P} 1 / 60)$, the upper $P$. mortilleti and $P$. picteti subzones are composed almost exclusively of nannoconid mudstones (P1/65 to P1/71e; Text-fig. 6).

\section{TOC, TS and TN}

Values are generally very low in the Puez 1 section (Table 1; Text-fig. 6). TOC is $<0.1 \%$ for most samples, and only in samples P1/43, P1/53, P1/71a and P1/71b do values exceed $0.2 \%$. TS values are on average $0.37 \%$ and do not show major trends. TN values, with average values of $0.06 \%$ as well as average calculated $\mathrm{C} / \mathrm{N}$ ratios of 1.15 , are very low. In contrast, samples Pnew/1 and Pnew/2 from the black shale intervals revealed significantly higher TOC $(7.0 \% / 5.7 \%)$ and TS values $(2.4 \% / 2.7 \%$; Text-fig. 3 ; Table 1$)$.

Table 2. Geochemical values for stable carbon isotopes $\left(\delta^{13} \mathrm{C}\right)$, total organic carbon (TOC), total sulphur (TS) and total nitrogen (TN) contents 
EVOLUTION OF THE SOUTHERN ALPS

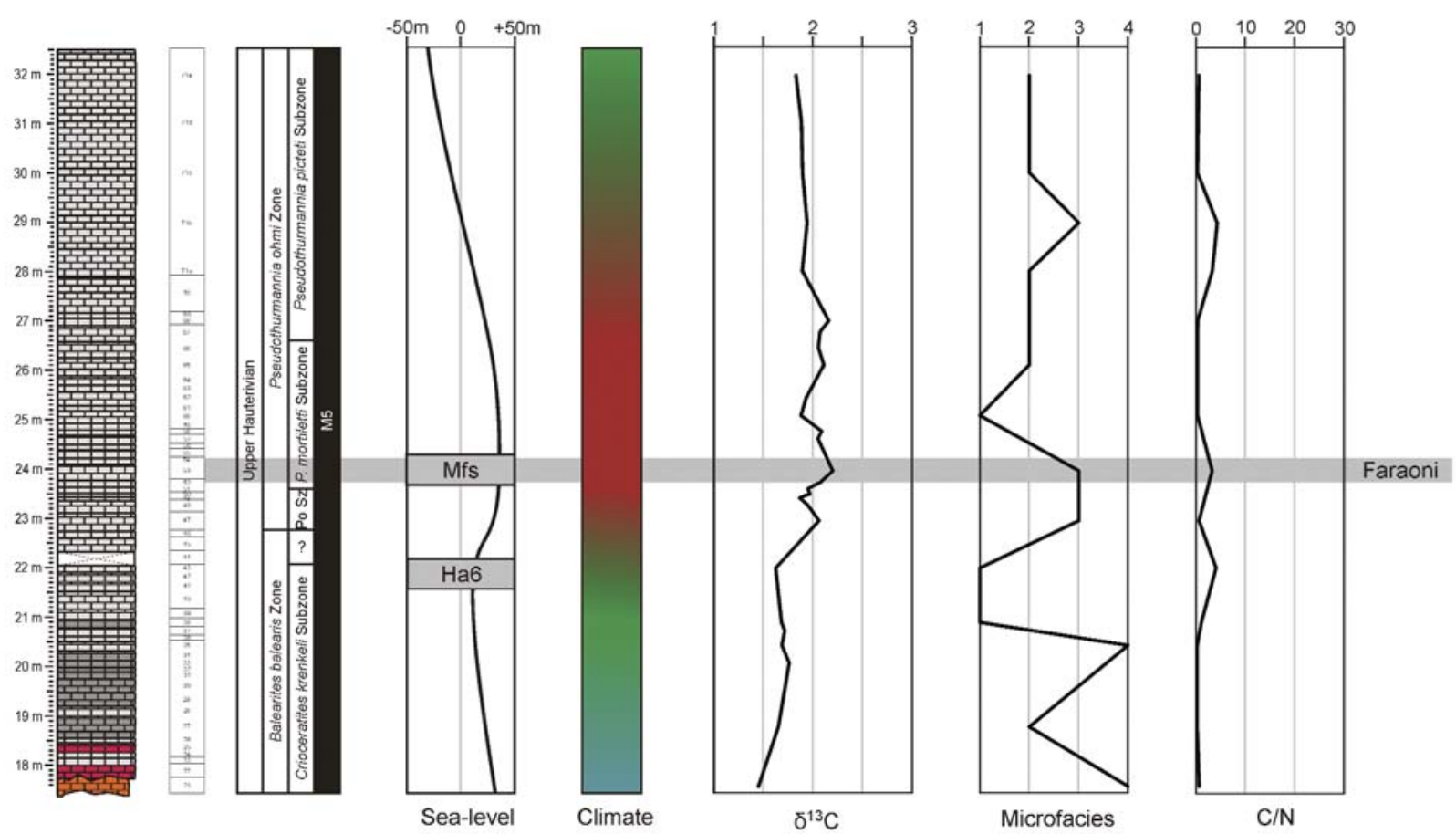

Text-fig. 6. Compiled results from bio-, magneto-, chemostratigraphical, geophysical, geochemical and microfacies analyses in the Puez 1 section. Microfacies types: (1) mudstone; (2) nannoconid mudstone; (3) radiolarian wackestone; (4) Radiolaria-sponge wackestone-packstone. Sea-level curve and sequence boundaries adapted from Hardenbol et al. (1998), Adatte et al. (2005) and Arnaud (2005). Ha6 = sequence boundary, Mfs = maximum flooding surface. For absolute age data see Ogg et al. (2008). Climatic trends from Föllmi (2012). See text for discussion

\section{DISCUSSION}

\section{Stratigraphic constraints for the section}

Based on its ammonite fauna (Lukeneder 2012), the studied interval ranges from the Crioceratites krenkeli Subzone to the lower Pseudothurmannia picteti Subzone (Reboulet et al. 2009). The $\delta^{13} \mathrm{C}_{\text {bulk }}$ record determined here confirms this correlation: its slightly increasing values correspond well to the isotopic trend observed throughout the uppermost Hauterivian Tethys (Erba et al. 1999; Schootbrugge et al. 2000; Godet et al. 2006; Föllmi 2012). While the magnitude of this positive trend $(0.6 \%)$ compares well with other isotopic records, $\delta^{13} \mathrm{C}_{\text {bulk }}$ of the Puez 1 section deviates from the general pattern in the abrupt increase of $0.4 \%$ in the Spathicrioceras seitzi and Pseudothurmannia ohmi subzones. Difficulties in identifying the $S$. seitzi and P. ohmi subzones (P1/41-49; Lukeneder 2012), as well as the diversity minimum in the ammonite fauna (see below; Hoedemaeker 1995), indicate that the sudden shift in the isotopic record reflects a condensed section or a hiatus during a sea-level lowstand. Furthermore, a similar pattern in ammonite assemblages has been observed in coeval deposits of the Betic Cordillera in Spain; these deposits have been linked to sequence boundary $\mathrm{Ha} 6$ in the upper Balearites balearis Zone (Hardenbol et al. 1998; Adatte et al. 2005; Arnaud 2005; Company et al. 2005).

The bio- and chemostratigraphic constraints indicate a correlation of the entire section to the normal magnetozone upper M5 (Ogg et al. 2008; = CM4 of Channell et al. 1995, 2000), which is in good agreement with previous studies from the Cismon area of the southeastern Trento Plateau (Erba et al. 1999).

\section{Identification of the Faraoni Level equivalent}

Previous studies have shown that the Faraoni Level and its equivalents occur within the Psedothurmannia mortilleti Subzone (= P. catulloi Subzone of Reboulet et al. 2009; e.g., Godet et al. 2006; Lukeneder 2012). In the Puez 1 section, the base of the P. mortilleti Subzone is marked by the first ocurrence of $P$. mortillet $i$ and the last occurrence of Crioceratites krenkeli in bed $\mathrm{P} 1 / 50$. This subzone ranges up to $\mathrm{P} 1 / 65$. The corresponding beds reveal a characteristic ammonite association of Pseudothurmannia mortilleti, P. pseudomalbosi, Honnoratia thiollierei, Hamulina sp., Anahamulina sp., Hamulinites munieri, Plesiospitidiscus subdifficilis and Plesiospitidiscus sp. (Text-fig. 


\section{ALEXANDER LUKENEDER AND PATRICK GRUNERT}

4). The subzone is also marked by the first occurrence of the family Pulchelliidae with Discoidellia cf. favrei and Discoidellia sp. The latter forms are accompanied by typical Phylloceratidae with Phylloceras tethys, Phyllopachyceras infundibulum, and by members of the Lytoceratidae such as Lytoceras subfimbriatum, $L$. sp. and L. anisoptychum. Similar uppermost Hauterivian faunas have been reported from the Maiolica Formation of the Lessini Mountains and Central Apennines (northeastern and central Italy) by Faraoni et al. (1995, 1996) and Cecca et al. (1998) (Text-fig. 3). The ammonoid fauna (29 species) described by Cecca et al. (1998) originates exclusively from a single bed, the "Guide bed D", the so-called Mediterranean Faraoni Level (see also Galeotti 1995; Baudin et al. 1997). Assemblages include the same members as seen at Puez, with Phyllopachyceras infundibulum, Eulytoceras anisoptychum, Pseudothurmannia catulloi, Psilotissotia favrei (= Discoidellia favrei), Plesiospitidiscus sp. and Emericiceras thiollieri (= Honnoratia thiollierei).

While the ammonite fauna restricts the Faraoni Level equivalent to beds $\mathrm{P} 1 / 50$ to $\mathrm{P} 1 / 65$, the $\delta^{13} \mathrm{C}_{\text {bulk }}$ data allow more precise considerations. In upper Hauterivian to lower Barremian isotopic records, the Faraoni Level falls within a minor positive trend in $\delta^{13} \mathrm{C}_{\text {bulk }}$ values that is also observed in the Puez $1 \mathrm{sec}-$ tion (Schootbrugge et al. 2000; Godet et al. 2006; Föllmi 2012). Erba et al. (1999) and Tremolada et al. (2009) reported $\delta^{13} C_{\text {bulk }}$ values for the upper Hauterivian of the southeastern Trento Plateau that are remarkably similar to those of the Puez 1 section. The Faraoni Level is characterised by a minor peak $(0.2 \%$ o above average values), which indicates the position of the Faraoni Level equivalent in bed P1/53 in the Puez 1 section (Text-fig. 6).

\section{Palaeoenvironmental framework for the upper Hauterivian Trento Plateau}

Whilst the opinions on the triggers of the Faraoni event differ, most authors agree on an eutrophication of surface waters and the development of an extensive oxygen-minimum zone in the Tethys. At the southern Trento Plateau, changes in the trophic structure are reflected in nannoconid abundance, as demonstrated for the Cismon core (Tremolada et al. 2009). There, a distinct drop in the absolute abundance of nannoconids occurs approximately at the base of chron upper M5 and culminates around the Faraoni Level. Nannoconid abundance recovers shortly after, yielding the peak values of the entire succession. The authors attribute the changes to a turnover in the trophic structure: while the nutricline was rather shallow before and during the Faraoni Level, a deepening of the nutricline resulted in blooms of nannoconids adapted to oligotrophic conditions. A similar pattern of nannoconid abundance is observed in the Puez area, suggesting a continuity in trophic structure between the southern and northern parts of the Trento Plateau during the latest Hauterivian. The revealed trends in microfacies suggest eutrophication for the lower part of the Puez succession, including the Faraoni Level equivalent (P1/21 to $\mathrm{P} 1 / 60$ ), whereas the nannoconid blooms in the upper part indicate oligotrophic conditions.

The low $\mathrm{C} / \mathrm{N}$ ratios suggest a marine origin of the organic matter. Changes in nutrient availability and productivity are reflected in the organic matter content (7.0\%/5.7\%; Text-fig 3; Table. 1) Similar to those of the southeastern part of the Trento Plateau (Baudin et al. 1997; Erba et al. 1999), TOC values are generally $<0.3 \%$ in the Puez 1 section. The low TOC values most likely reflect poor preservation due to a well-oxygenated environment. Such an environment is also reflected in very low sulphur values and frequent bioturbation. Two brief episodes of oxygen-depleted conditions are indicated by high TOC and sulphur values of the thin black shale layers in the upper part of bed P1/53 (Table 1; Text-fig. 3). These observations along the eastern margin of the Trento Plateau contrast with the common occurrence of thick black shales and TOC values up to $11 \%$ in the southwestern part of the plateau (Baudin et al. 1997). The latter authors suggested a tentative depositional model based on palaeotopography to explain the west-east gradient: while the elevated western part of the Trento Plateau extended into the massive oxygen-minimum zone, its eastern part was situated in the deeper, better oxygenated part below the oxygen-depleted layer (Baudin et al. 1997).

\section{Ammonite assemblage changes}

The revealed trends in ammonite diversity and life-habitat groups allow a comparison between the Betic Cordillera in Spain (Company et al. 2005) and the northern part of the Trento Plateau, yielding new insights into the palaeoenvironment.

Both data sets agree in the strongly increasing diversity of epipelagic vertical migrants and planktic drifters during the Pseudothurmannia mortiletti and $P$. picteti subzones. Company et al. (2005) relate this distinct turnover in the ammonite fauna to phytoplankton blooms during the Faraoni event and the coeval $2^{\text {nd }}$-order peak transgression in the lower P. mortilleti Zone. The increase in trophic resources favoured 
the diversification of planktic ammonites. In the Puez area, similar blooms in productivity are expressed as radiolarian wackestones. This assumption, however, does not explain why this life-habitat group remains diverse in the aftermath of the Faraoni event in the upper P. mortiletti and P. picteti subzones when oligotrophic conditions were established (Tremolada et al. 2009). These contrasting trends show the difficulties in interpreting ammonite life-habitat groups and feeding strategies.

Although there is a general agreement in the diversity patterns of epipelagic vertical migrants and planktic drifters, the trends of the other life-habitat groups differ in two respects between the two areas: (1) The reduction in all morphological groups during the Spathicrioceras seitzi and P. ohmi subzones is observed only in the Puez 1 section. As previously discussed, this most likely reflects condensed sedimentation during a sea-level lowstand. Minima in ammonite diversity during sea-level lowstands have been shown previously and demonstrate the strong link of the ammonite fauna to sea-level changes (Hoedemaeker 1995).

(2) In strong contrast to the assemblages from the Betic Cordillera in Spain, the deep nektic groups do not decrease during the Faraoni event on the Trento Plateau. Company et al. (2005) explained the extinction of deep nektic groups around the Faraoni Level by an oxygen-minimum zone that developed due to phytoplankton blooms. As previously discussed, a better oxygenated environment that did not affect the deep nektic groups is assumed for the eastern part of the Trento Plateau. Faunal turnover during the Faraoni event is related to more complex factors than the simplistic productivity/oxygen-depletion scenario, and local triggers have to be taken into account.

\section{An alternative depositional model for the Trento Plateau during the uppermost Hauterivian}

Baudin et al. (1997) suggested a tentative depositional model to explain the west-east gradient in organic matter preservation: while the elevated western part of the Trento Plateau extended into the massive oxygen-minimum zone, its eastern part was situated in the deeper, better oxygenated part below the oxygendepleted layer. This currently accepted depositional model for the upper Hauterivian Trento Plateau assumes (without giving any data) a water depth of 1,000-1,500 $\mathrm{m}$ at the lower limit of the oxygen-minimum zone (Baudin et al. 1997; Erba et al. 1999). The data presented herein are not entirely consistent with this model and might be better explained by an alter- native scenario favouring a shallower water depth slightly above the oxygen-minimum zone.

A shallower water depth is indicated both by the expression of sea-level change in the sediment as well as by the ammonite faunas. The link between sea level and ammonite diversity has been previously observed (Hoedemaeker 1995). Diversity minima occur during sea-level lowstands, while maxima occur during maximum flooding and at the corresponding maximum flooding surface. This pattern is clearly observed at Puez. Interestingly, during the general reduction of ammonite morphogroups, mostly mesopelagic ammonites were affected while epipelagic families showed a more moderate decrease. This suggests a shallowing of the water depth towards the epi/mesopelagic boundary: a water depth beween 200 and $300 \mathrm{~m}$ seems realistic for this period. Assuming a sea-level change in the order of $25 \mathrm{~m}$, as well as incorporating potential tectonic movements, would yield a general water depth between 200 and $500 \mathrm{~m}$ during the latest Hauterivian.

Further evidence for a shallower water depth is documented in the sediment. The condensed section probably reflects stronger bottom currents, possibly amplified by the shallowing water depth and related to E-W-directed currents in the Tethys (Pucéat et al. 2005). In the microfacies, higher water energy is indicated by biomicritic, slightly laminated biogenic components (biogenic oozes containing bivalves, crinoids, radiolaria, ostracods and foraminifera) within nannoconid mudstone.

These observations give rise to a new depositional model (Text-fig. 7). Note that the tectonic history of the Trento Plateau is not considered in this and previous models; this history should be further studied in order to more accurately reconstruct the palaeotopography. Nonetheless, because both the ammonite diversity and the sedimentation are linked largely to the global sealevel signal, tectonic movements are considered of minor significance.

During the Crioceratites krenkeli Subzone a slow sea-level fall occurred, perhaps accompanied by uplift. Epipelagic and mesopelagic ammonite morphogroups occurred commonly, indicating a water depth between 300 and $500 \mathrm{~m}$. A sea-level lowstand occurred in the Spathicrioceras seitzi and Pseudothurmannia ohmi subzones, corresponding to sequence boundary Ha6. The condensed section indicates stronger bottom currents that prevented continuous sedimentation on the plateau. Mesopelagic ammonites were affected by a severe turnover. Although this might be partly attributed to the condensed section, we assume a shallowing of the water depth towards the euphotic zone of around $200 \mathrm{~m}$. 
During the Faraoni event the eastern part of the Trento Plateau was situated approximately at the upper limit of the oxygen-minimum zone, and was affected occasionally by oxygen depletion (varying with sea level and productivity). In contrast, the western part of the plateau clearly ranged within the upper part of the oxygen-depleted layer, promoting the preservation of abundant organic matter (Baudin et al. 1997).

Finally, during highstand conditions in the Pseudothurmannia mortiletti and P. picteti subzones, nannoconid mudstones were deposited. All ammonite morphogroups were present and the ammonite families showed the highest diversity. The constant presence of mesopelagic ammonites suggests a deepening to 300 $500 \mathrm{~m}$.

\section{CONCLUSIONS}

New stratigraphic and palaeoenvironmental data are presented from an upper Hauterivian succession of hemipelagic and pelagic limestones in the northeastern part of the Trento Plateau in the Puez area of the
Dolomites (Southern Alps, Italy). The studied section is correlated to the Balearites balearis and "Pseudothurmannia ohmi" zones and normal palaeomagnetic chron upper M5. The c. 30-cm-thick bed P1/53 is identified as the Faraoni Level equivalent based on its position within the Pseudothurmannia mortilleti Subzone and on the positive plateau of a minor positive trend in the $\delta^{13} \mathrm{C}_{\text {bulk }}$ record. The correlation is further strengthened by the ammonite fauna, which is very similar to that of the marker bed of the Umbria Marche type region ("guide bed D"; Cecca et al. 1998).

Microfacies and geochemical proxies of the Puez 1 section compare well with those of outcrops and borehole cores from the southeastern part of the Trento Plateau and indicate a parallel evolution of both areas. Trends in radiolarian and nannoconid abundances suggest a turnover in the trophic structure of the surface water from eutrophication around the Faraoni event to oligotrophic conditions. These changes in primary productivity, however, are not reflected in the organic matter, which is generally very low (TOC $<0.3 \%$ ). Together with very low sulphur values $(<0.4 \%)$ and the
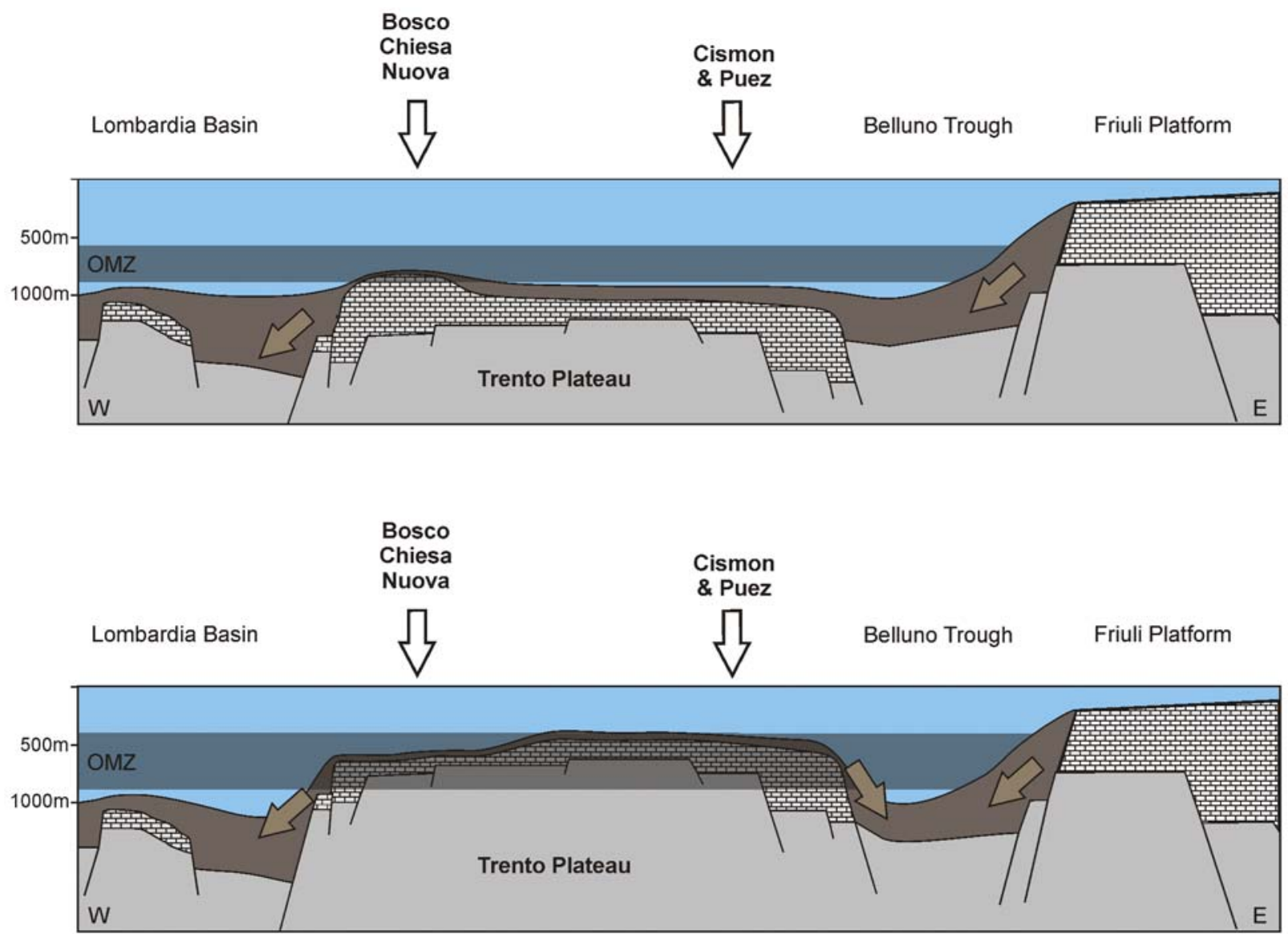

Text-fig. 7. A - Depositional model of Baudin et al. (1997) and Erba et al. (1999) for the Trento Plateau during the Faraoni event. B - Alternative depositional model presented in the present contribution. See text for discussion 
frequent occurrence of bioturbation throughout the studied section, a well-oxygenated environment is indicated. Two brief episodes of oxygen-depleted conditions are indicated by high TOC and sulphur values of thin black shale layers in the upper part of bed $\mathrm{P} 1 / 53$.

The analysis of ammonite diversity and life-habitat groups suggests a strong influence of sea level on the plateau. While epi- and mesopelagic ammonites occur commonly in the Crioceratites krenkeli, Pseudothurmannia mortiletti and P. picteti Subzones, a severe reduction in all life-habitat groups occurred during the sea-level lowstand of the Spathicrioceras seitzi and $P$. ohmi subzones. The Faraoni event is heralded by an ammonite faunal turnover characterized by an increasing diversity of epipelagic ammonites. Although a similar trend has been observed in the Betic Cordillera in Spain, the trend differs in the common occurrence of deep nektic ammonites, related to a better oxygenated environment on the Trento Plateau.

The new data reveal not only a continuity of palaeoenvironmental conditions between the northern and southern parts of the Trento Plateau, they also shed light on the expression of the Faraoni event in the area. The palaeoenvironmental conditions along the eastern part of the Trento Plateau during the Faraoni event contrast with those related to the deposition of organic-rich black shales in the western part of the Plateau. The new data help to re-evaluate previous studies that proposed a depositional model with a west-east topographic gradient along the plateau: while the elevated western areas of the plateau ranged within a well-developed oxygen-minimum zone during the Faraoni event, the deeper eastern areas were situated below the dysoxic layer. An alternative depositional model proposed here considers a significantly shallower water depth of 300-500 m. During the sealevel lowstand the reduction in mesopelagic ammonites suggests a shallowing towards the epi/mesopelagic boundary. During the Faraoni event, the eastern areas of the Trento Plateau were located at the upper limit of the oxygen-minimum layer and were thus only occasionally affected by oxygen depletion, indicated by high TOC and sulphur values, while the western areas were situated within the upper part of the oxygen-depleted layer.

Further investigations at the stratotype of the Puez Formation will be conducted in the framework of the Dolomite project P20018-N10 (Austrian Science Fund/FWF) in order to test the proposed depositional model, and to evaluate the implications of the new model for other anoxic events of the Cretaceous recorded on the Trento Plateau.

\section{Acknowledgements}

The authors would like to thank Luigi Jovane, Jairo Savian (both University of São Paulo, São Paulo), Fabio Florindo (Istitute Nazionale di Geofisica e Vulcanologfia, Rome) and Monika Sieghardt (University of Vienna, Vienna) for performing paleomagnetic and geochemical analyses. Daniela Rehákova, Eva Halásová and Štefan Józsa (all Comenius University, Bratislava) and Ján Soták (Slovakian Academy of Sciences, Banská Bystrica) provided preliminary data on microfacies. Mario Sprovieri (Università di Palermo, Pelermo) is acknowledged for his isotope analyses and Sylvain Richoz (University of Graz) for many helpful discussions. The manuscript was improved by comments of Stéphane Bodin (Ruhr University Bochum), an anonymous reviewer and the additional comments of Ireneusz Walaszczyk (University of Warsaw, Editor-in-Chief AGP). Sincere thanks go to Evelyn Kustatscher, Benno Baumgarten and Vito Zingerle (all Museum of Nature South Tyrol) for their organisational help. We thank Michl Laimer (Bozen), official provincial government for "Raumordnung, Umwelt und Energie" as well as Arthur Kammerer and Astrid Wiedenhofer (both Office for Natural Parks South Tyrol), who provided an excavation permit in the Puez-Geisler Natural Park. This study was financially supported by the Austrian Science Fund (FWF) and contributes to project P20018-N10.

\section{REFERENCES}

Adatte, T., Arnaud-Vanneau, A., Arnaud, H., Blanc-Aletru, M.C., Bodin, S., Carrio, E., Föllmi, K.B., Godet, A., Raddadi, M.C. and Vermeulen, J. 2005. The Hauterivian - Lower Aptian sequence stratigraphy from Jura Platform to Vocontian Basin: a multidisciplinary approach. Géologie Alpine, série spéciale "colloques et excursions", 7, $181 \mathrm{p}$.

Arnaud, H. 2005. Sequence stratigraphy interpretation, In: Aadatte, T. et al. (Eds), The Hauterivian - Lower Aptian sequence stratigraphy from Jura platform to Vocontian basin: a multidisciplinary approach. Géologie Alpine, pp. 174 179. Série Spéciale "Colloques et Excursions", 7.

Arthur, M.A., S. Hagerty, W.E. Dean, G.E. Claypool, T. Dawes, D. McManaman, P.A. Meyers and Dunham, K. 1986. A geochemical note: comparison of techniques for obtaining $\mathrm{CaCO}_{3}$, organic carbon and total nitrogen in limestones and shales, In: Rad, U. von and Wise, S.W. (Eds), Initial Reports of the DSDP, 93, 1263-1268.

Barrier, E. and Vrielynck, B. 2008. Palaeotectonic maps of the Middle East, CCGM, 14 maps.

Baudin, F. 2005. A Late Hauterivian short-lived anoxic event in the Mediterranean Tethys: the "Faraoni Event". Comptes Rendus Geosciences, 337, 1532-1540. 
Baudin, F., Bulot, L.G., Cecca, F., Coccioni, R., Gardin, .S. and Renard, M. 1999. Un équivalent du "Niveau Faraoni" dans le bassin du Sud-Est de la France, indice possible d'un événement anoxique fini-hauterivien étendu à la Téthys méditerranéenne. Bulletin de la Société Géologique de France, 170, 487-498.

Baudin, F., Cecca, F., Galeotti, S. and Coccioni, R. 2002. Palaeoenvironmental controls of the distribution of organic matter within a Corg-rich marker bed (Faraoni Level, uppermost Hauterivian, central Italy). Eclogae geologicae Helvetiae, 95, 1-13

Baudin, F., Faraoni, P., Marini, A. and Pallini, G. 1997. Organic matter characterisation of the "Faraoni Level" from Northern Italy (Lessini Mountains and Trento Plateau): comparison with that from Umbria Marche Apennines. Palaeopelagos, 7, 41-51.

Bellanca, A., Erba, E., Neri, R., Premoli Silva, I., Sprovieri, M., Tremolada, F. and Verga, D. 2002. Palaeoceanographic significance of the Tethyan "Livello Selli" (early Aptian) from the Hybla Formation, northwestern Sicily: biostratigraphy and high-resolution chemostratigraphic records. Palaeogeography, Palaeoclimatology, Palaeoecology, 185, 175-196.

Bersezio, R., Erba, E., Gorza, M. and Riva, A. 2002. BerriasianAptian black shales of the Maiolica Formation (Lombardian Basin, southern Alps, northern Italy): local to global events. Palaeogeography, Palaeoclimatology, Palaeoecology, 180, 253-275.

Bodin, S., Godet, A., Föllmi, K.B., Vermeulen, J., Arnaud, H., Strasser, A., Fiet, N. and Adatte, T. 2006. The late Hauterivian Faraoni oceanic anoxic event in the western Tethys: Evidence from phosphorous burial rates. Palaeogeography, Palaeoclimatology, Palaeoecology, 235, 245 264.

Bodin, S., Fiet, N., Godet, A., Matera, V., Westermann, S., Clément, A., Janssen, N.M.M., Stille, P. and Föllmi, K.B. 2009. Early Cretaceous (late Berriasian to early Aptian) palaeoceanographic change along the northwestern Tethyan margin (Vocontian Trough, southeastern France): $\delta^{13} \mathrm{C}, \delta^{18} \mathrm{O}$ and $\mathrm{Sr}$-isotope belemnite and whole-rock records. Cretaceous Research, 30, 12471262.

Bodin, S., Godet, A., Matera, V., Steinmann P., Vermeulen, J., Gardin. S., Adatte, T., Coccioni, R. and Föllmi, K.B. 2007. Enrichment of redox-sensitive trace metals (U, V, Mo, As) associated with the late Hauterivian Faraoni oceanic anoxic event. Internation al Journal of earth Sciences, 96, 237-341.

Bosellini, A. 1998. Die Geologie der Dolomiten. 192 pp. Verlagsanstalt Athesia, Bozen/Bolzano.

Bosellini, A., Gianolla, P. and Stefani, M. 2003. Geology of the Dolomites. Episodes, 26, 181-185.

Busnardo, R., Charollais, J., Weidmann, M. and Clavel, B.
2003. Le Crétacé inférieur de la Veveyse de Châtel (Ultrahelvétique des Préalpes externes; canton de Fribourg, Suisse). Revue de Paléobiologie, 22, 1-174.

Cecca, F. 1998. Early Cretaceous (pre-Aptian) ammonites of the Mediterranean Tethys: palaeoecology and palaeobiography. Palaeogeography, Palaeoclimatology, Palaeoecology, 138, 305-323.

Cecca, F., Marini, A., Pallini, G., Baudin, F. and Begouen, V. 1994a. A guide level of the uppermost (Lower Cretaceous) in the pelagic succession of Umbria - Marche Apennines (Central Italy): the Faraoni Level. Rivista Italiana di Paleontologia e Stratigrafia, 99, 551-568.

Cecca, F., Pallini, G., Erba, E., Premoli-Silva, I. and Coccioni, R., 1994b. Hauterivian - Berremian chronostratigraphy based on ammonites, nannofossils, planktonic foraminifera and magnetic chrons from the Mediterranean domain. Cretaceous Research, 15, 457-467.

Cecca, F., Faraoni, P., Marini, A. and Pallini, G. 1995. Fieldtrip across the representative sections for the Upper Hauterivian - Barremian ammonite biostratigraphy in the Maiolica exposed at Monte Nerone, Monte Petrano and Monte Catria (Umbria-Marche Apennines). Memorie descrizione della Carta Geologiche d'Italia, 51, 187-211.

Cecca, F., Gáleotti, S., Coccioni, R., and Erba, E. 1996. The equivalent of the "Faraoni Level" (Uppermost Hauterivian, Lower Cretaceous) recorded in the eastern part of Trento Plateau (Venetian Southern Alps, Italy). Rivista Italiana di Paleontologia e Stratigrafia, 102, 417-424.

Cecca, F., Faraoni, P. and Marini, A. 1998. Latest Hauterivian (Early Cretaceous) ammonites from Umbria-Marche Apennines (Central Italy). Palaeontographia Italica, 85, 61-110.

Channell, J.E.T., Cecca, F. and Erba, E. 1995. Correlations of Hauterivian and Barremian (Early Cretaceous) stage boundaries to polarity chrons. Earth and Planetary Science Letters, 134, 125-140.

Channel, J.E.T., Erba, E., Muttoni, G. and Tremolada, F. 2000. Early Cretaceous magnetic stratigraphy in the APTICORE drill core and adjacent outcrop at Cismon (Southern Alps, Italy), and correlation to the proposed Barremian-Aptian boundary stratotype. Geological Society of America Bulletin, 112, 1430-1443.

Coccioni, R., Baudin, F., Cecca, F., Chiari, M., Galeotti, S., Gardin, S. and Salvini, G. 1998. Integrated stratigraphic, palaeontological, and geochemical analysis of the uppermost Hauterivian Faraoni section in the Fiume Bosso section, Umbria-Marche Apennines, Italy. Cretaceous Research, 19, 1-23.

Coccioni, R., Luciani, V. and Marsili, A. 2006. Cretaceous anoxic events and radially elongated chambered planktonic forminifera: paleoecological and paleooceanographic implications. Palaeogeography, Palaeoclimatology, Palaeoecology, 235, 66-92. 
EVOLUTION OF THE SOUTHERN ALPS

Company, M., Sandoval, J. and Tavera, J.M. 2002. Ammonite bioevents and zonation of the uppermost Hauterivian Betic Cordillera (SE Spain). Documents du Laboratoire de Géologie de Lyon, 156, 83-84.

Company, M., Sandoval, J. and Tavera, J.M. 2003. Ammonite biostratigraphy of the uppermost Hauterivian in the Betic Cordillera (SE Spain). Geobios, 36, 685-694.

Company, M., Aguado, R., Sandoval, J., Tavera, J.M., Jimenez de Cisneros, C. and Vera, J.A. 2005. Biotic changes linked to a minor anoxic event (Faraoni Level, Latest Hauterivian, Early Cretaceous). Palaeogeographie, Palaeoclimatology, Palaeoecology, 224, 186-199.

Company, M., Sandoval, J., Tavera, J.M., Aoutem, M. and Ettachfini, M. 2008. Barremian ammonite faunas from the western High Atlas, Morocco - biostratigraphy and palaeobiogeography. Cretaceous Research, 29, 9-26.

Dercourt, J., Ricou, L.E. and Vrielynck, B., 1993. Atlas Tethys Palaeoenvironmental Maps. p. 307, Gauthier-Villars, Paris, (with 14 maps).

Dunham, R.J. 1962. Classification of carbonate rocks according to their depositional texture, In: Ham, W.E. (Ed.), Classification of carbonate rocks - a symposium. pp 108121. American Association of Petroleum Geologists, Memoire, 1.

Emerson, S. and Hedges, J.I. 1988. Processes controlling the organic carbon content of open ocean sediments. Paleoceanography, 3, 621-634.

Emiliani, C. 1991. Planktic/planktonic, nektic/nektonic, benthic/benthonic. Journal of Paleontology, 65, 329.

Erba, E., Channell, J.E.T., Claps, M., Jones, C., Larson, R., Opdyke, B., Premoli-Silva, I., Riva, A., Salvini, G. and Torricelli, S. 1999. Integrated stratigraphy of the Cismon Apticore (southern Alps, Italy): a "reference section" for the BarremianeAptian interval at low latitudes. Journal of Foraminiferal Research, 29, 371-391.

Faraoni, P., Marini, A. and Pallini, G. 1995. The Hauterivian ammonite succession in the Central Apennines, Maiolica formation (Petrano Mt., Cagli -PS). Preliminary results. Palaeopelagos, 5, 227-236.

Faraoni, P., Marini, A., Pallini, G. and Pezzoni, N. 1996. The Maiolica Fm. of the Lessini Mts and Central Apennines (North Eastern and Central Italy): a correlation based on new bio-lithostratigraphical data from the uppermost Hauterivian. Palaeopelagos, 6, 249-259.

Föllmi, K.B., Bôle, M., Jammet, N., Froidevaux, P., Godet, A., Bodin, S., Adatte, T., Matera, V., Fleitmann, D. and Spangenberg, J.E. 2011. Bridging the Faraoni and Sell oceanic anoxic events: short and repetitive dys- and anaerobic episodes during the late Hauterivian to early Aptian in the central Tethys. Climate of the Past Discussions, 7, 2021-2059.

Föllmi, K.B. 2012. Early Cretaceous life, climate and anoxia. Cretaceous Research, 35, 230-257.
Fourcade, E., Azema, J., Cecca, F., Dercourt, J., Guiraud, R., Sandulescu, M., Ricou, L.-E., Vrielynck, B., Cottereau, N. and Petzold, M., 1993. Late Tithonian (138 to $135 \mathrm{Ma}$ ), In: Dercourt, J., Ricou, L.E. and Vrielynck, B. (Eds), Atlas Tethys Palaeoenvironmental Maps. Beicip-Franlab, RueilMalmaison.

Galeotti, S. 1995. The palynoforaminifera of the Faraoni Level and Selli Level of the Umbria-Marche sequence. Palaeopelagios, 5, 3-18.

Geyer, O.F. 1993. Die Südalpen zwischen Friaul und Gardasee. Sammlung Geologischer Führer, 86, 576 p. Bornträger; Berlin-Stuttgart.

Godet, A., Bodin, S., Föllmi, K.B., Vermeulen, J., Gardin, S., Fiet, N., Adatte, T., Berner, Z., Stüben, D. and Schootbrugge, B.v.d. 2006. Evolution of the marine stable carbonisotope record during the early Cretaceous: A focus on the late Hauterivian and Barremian in the Tethyan Realm. Earth and Planetary Science Letters, 242, 254-271.

Godet, A., Bodin, S., Adatte, T. and Föllmi, K.B. 2008. Platform-induced clay-mineral fractionation along a northern Tethyan basin-platform transect: implications for the interpretation of Early Cretaceous climate change (late Hauterivian-early Aptian). Cretaceous Research, 29, 830-847.

Hardenbol, J., Thierry, J., Farley, M.B., Jacquin, T., Graciansky, P-C. de, and Vail, P.R. 1998. Mesozoic and Cenozoic sequence chronostratigraphic framework of European Basins, In: Graciansky, P-C. de, Hardenbol, J., Jacquin, T. and Vail, P.R. (Eds), Mesozoic and Cenozoic sequence stratigraphy of European Basins. pp. 3-13. SEPM Special Publication, 60.

Hennig, S., Weissert, H. and Bulot, L. 1999. C-isotope stratigraphy, a calibration tool between ammonite- and magnetostratigraphy: the Valanginian-Hauterivian transition. Geologica Carpatica, 50, 91-96.

Hirano, H. 1993. Phyletic evolution of desmoceratine ammonoids through the Cenomanian-Turonian oceanic anoxic event, In: House, M.R. (Ed.), The Ammonoidea: environment, ecology, and evolutionary change. pp. 267-283. Clarendon Press; Oxford.

Hunt, J.M. 1996. Petroleum Geochemistry and Geology. W.H. Freeman and Company; New York.

Kirschvink, J.L. 1980. The least-squares line and plane and the analysis of palaeomagnetic data. Geophysical Journal of the Royal Astronomical Society, 62, 699-718.

Kruta, I., Landman, N, Rouget, I., Cecca, F. and Tafforeau, P. 2011. The role of ammonites in the Mesozoic food web revealed by jaw preservation. Science, 331, 70-72.

Lukeneder, A. 2008. The ecological significance of solitary coral and bivalve epibionts on Lower Cretaceous (Valanginian-Aptian) ammonoids from the Italian Dolomites. Acta Geologica Polonica, 58, 425-436.

Lukeneder, A. 2010. Lithostratigraphic definition and stratotype for the Puez Formation: formalisation of the Lower Cre- 
taceous in the Dolomites (S. Tyrol, Italy). Austrian Journal of Earth Sciences, 103, 138-158.

Lukeneder, A. 2011. The Biancone and Rosso Ammonitico facies of the northern Trento Plateau (Dolomites, Southern Alps, Italy). Annalen des Naturhistorischen Museum Wien, 113A, 9-33.

Lukeneder, A. 2012. New biostratigraphic data of an Upper Hauterivian - Upper Barremian ammonite assemblage from the Dolomites (Southern Alps, Italy). Cretaceous Research, 35, 1-21.

Lukeneder, A. and Aspmair, C. 2006. Startigraphic implication of a new Lower Cretaceous ammonoid fauna from the Puez area (Valanginaian - Aptian, Dolomites, Southern Alps, Italy). Geo.Alp, 3, 55-91.

Lukeneder, A, Uchman, A, Gaillard, C. and Olivero, D. 2012. The late Barremian Halimedides horizon of the Dolomites (Southern Alps, Italy). Cretaceous Research, 35, 199-207.

Mutterlose, J. and Bornemann, A. 2000. Distribution and facies patterns of Lower Cretaceous sediments in northern Germany: a review. Cretaceous Research, 21, 733-759.

.Muttoni, G., Erba, E., Kent, D.V. and Bachtadse, V. 2005. Mesozoic Alpine facies deposition as a result of past latidudinal plate motion. Letters to Nature, 434, 59-63.

Ogg, J.G., Ogg, G. and Gradstein, F.M. 2008. The Concise Geologic Time Scale. 177 p. Cambridge University Press; Cambridge.

Peters, K.E., Walters, C.C. and Moldowan, J.M. 2005. The Biomarker Guide, Volume 2: Biomarkers and Isotopes in the Petroleum Exploration and Earth History, Second Edition, 1132 p. Cambridge University Press.

Pozzi, E. 1993. Die Fossilien der Dolomiten. 176 pp. Tappeiner Verlag; Lana.

Reboulet St., Klein J., Barragan R., Company M., GonzalezArreola C., Lukeneder A., Raissossadat S.N., Sandoval J., Szives O., Tavera J.M., Vašíček Z., and Vermeulen J. 2009. Report on the 3rd international Meeting on the IUGS Lower Cretaceous Ammonite Working Group, the "Kilian Group" (Vienna, Austria, 15th April 2008). Cretaceous Research, 30, 496-592.

Schootbrugge, B. van de, Föllmi, K.B., Bulot, L.G. and Burns, S.J. 2000: Paleoceanographic changes during the Early Cretaceous (Valanginian-Hauterivian): Evidence from oxygen and carbon stable isotope. Earth and Planetary Science Letters, 181, 15-31.

Scotese, C.R. 2001. Atlas of Earth History. Paleomap project. 52 p. Arlington, Texas.
Seilacher, A, and Gunji, P.Y. 1993. Morphogenetic countdowns in heteromorphic shells. Neues Jahrbuch für Geologie und Paläontologie, Abhandlungen, 190, 237-265.

Spötl, C. and Vennemann, T.W. 2003. Continuous-flow isotope ratio mass spectrometric analysis of carbonate minerals. Rapid Communications in Mass Spectrometry, 17, 1004 1006.

Stampfli, G. and Mosar, J. 1999. The making and becoming of Apulia. Mémoires Science Géologie (University of Padova). Special volume, $3^{\text {rd }}$ Workshop on Alpine Geology, 51, Padova.

Stampfli, G.M., Borel, G.D., Marchant, R and Mosar J. 2002. Western Alps geological constraints on western Tethyan reconstructions, In: Rosenbaum, G. and Lister, G.S. 2002 (Eds), Reconstruction of the evolution of the Alpine-Himalayan Orogen. Journal of Virtual Explorer, 8, 77-106.

Tremolada, F., Erba, E., bernardi, B.de and Cecca, F. 2009. Calcareous nannofossil fluctuation during the late Hauterivian in the Cismon core (Venetian Alps, northeastern Italy) and in selected sections of the Umbria-Marche Basin (central Italy): paleoceanographic implications of the Faraoni Level. Cretaceous Research, 30, 505-514.

Wagner, T. and Dupont, L.M. 1999. Terrestrial Organic Matter in Marine Sediments: Analytical Approaches and Eolian-Marine Records in the Central Equatorial Atlantic, In: Fischer, G. and Wefer, G. (Eds), Use of proxies in paleoceanography, pp. 547-574.

Weissert, H.J. 1981. Depositional processes in an ancient pelagic environment: the Lower Cretaceous Maiolica of the Southern Alps. Eclogae Geologicae Helvetiae, 74, 339352.

Weissert, H. 1989. C-isotope stratigraphy, a monitor of paleoenvironmental changes: A case study from the Early Cretaceous. Survey in Geophysics, 10, 1-16.

Weissert H., McKenzie J.A. and Channell J.E.T. 1985. Natural variations in the carbon cycle during the Early Cretaceous. In The carbon cycle and atmospheric $\mathrm{CO}_{2}$ : Natural variations Archean to the present. Geophysical Monograph, 32, 531-545.

Weisser, H., Joachimski, M. and Sarnthein, M. 2008. Chemostratigraphy. Newsletters on Stratigraphy, 42, 145179.

Westermann, G.E.G. 1990. Ammonoid life and habitat, In: Landman, N., Tanabe, K. and Davis, R.A. (Eds), Ammonoid Paleobiology. pp. 607-707. Plenum Press; New York. 